\title{
Sector-Specific, Monetary Policy, and Macroeconomic Determinants of Business Dynamics: Evidence from Financial Services Industry in Malaysia
}

\author{
Yee Ern Hui ${ }^{1}$, Wong Mei Foong ${ }^{1 *}$ \\ ${ }^{l}$ Faculty of Accountancy, Finance \& Business, Tunku Abdul Rahman University College, Jalan Genting Kelang, Setapak, \\ 53300 Kuala Lumpur, Malaysia. \\ *Corresponding author. Email: wongmf@tarc.edu.my
}

\begin{abstract}
This paper examines the effects of sector-specific factors, macroeconomic factors, and monetary policy factors on business dynamic of Malaysian financial services industry. The study employed the whole public-listed financial services industry in Malaysia consisting of 10 public-listed banks, 9 insurance institutions, and 14 other financial institutions. In considering the crisis factor, four models have been developed for each sector: a) First and second models make distinctive comparison on the effect of financial crisis dummy variable during 2008-09, b) Third and fourth models investigate the dataset separately from the year 2000 to 2007, and from the year 2010 to 2019 respectively, particularly, pre-crisis period, and post-crisis period. This study found that there exists significant relationship among sector-specific factors, economic factors, and monetary policy factors, as well as business dynamics across banks, insurance, and other financial institutions industry. Nevertheless, by factoring in crisis factors, the impact seems to be mere significant across three industries which indicate that income activities will lead to bank and non-bank activities which is less fluctuated to systemic crisis.
\end{abstract}

Keywords: Business dynamics, sector-specific, macroeconomic, monetary policy, financial services industry

\section{INTRODUCTION}

Financial services industry presents as the main element in promoting monetary and financial stability of the country. Especially for developing and emerging countries, the industry has a predominant role in ensuring the countries' economy to grow at a sustainable rate. This paper attempts to investigate the impact of sector-specific factors, monetary policy, and macroeconomic factors on the financial services industry that includes banking sector, insurance sector, and other financial institutions in Malaysia as a whole. In Malaysia, the listed financial-services companies consist of commercial banks, Islamic banks, international Islamic banks, investment banks, other financial institutions, and licensed insurance companies and takaful operators.

First, looking into the banking industry in Malaysia, the dual-banking system runs parallelly. Dual-banking system is known as the two co-exist systems that operate together but serve different needs in banking roles - which are conventional financial system and Islamic financial system. The central bank of Malaysia (BNM) is well-known for its primary role of promoting monetary and financial stability conducive to the sustainable growth in the Malaysian economy. Meanwhile, the banks in Malaysia's dualbanking system can be categorized into Malaysiancontrolled institutions and foreign-controlled institutions.
The country-wide banks in Malaysia carry out supporting role in the country's economic activities. At the same time, Malaysia is well-known for its Islamic financial hub as Islamic financial system in Malaysia is regulated stringently by authorities and oversees by the Syariah Committee. Islamic banking, takaful and retakaful (Islamic Insurance and re-insurance), Islamic interbank money market, and Islamic capital market operate together in the Islamic financial system in Malaysia.

Subsequently, the insurance sector consists of insurance and reinsurance companies for both Islamic and non-Islamic. This sector provides general and life-insurance products to the public as well as creates a saving platform for future needs. Turning to the last sector in the financial services industry, the other financial institutions such as development financial institutions (DFIs) carry different roles in the country. Government established the DFIs to benefit the overall socio-economic development.

The Financial Sector Masterplan (FSMP) over the period 2001-2010 act as the reformative strategies to recover from financial crisis. Meanwhile, the Financial Sector Blueprint for the period 2011-2020 is the continuous effort from the previous masterplan. In the early 2000s, domestic commercial banks and finance companies were mandatory to merge and form ten financial conglomerates to strengthen the financial system under the consolidation program of FMSP 2001-2010. In year 2003, there was only 10 
commercial banks left after merging. CIMB Bank had acquired Southern Bank in the year 2006 and Hong Leong Bank had acquired EON Bank in the year 2011. As of 2017, there was only 8 commercial banks left in operation. In contrast, there is an increasing number of foreign-controlled banks due to the liberalization and deregulation of foreign entry. Although foreign banks are increasing, the branches of foreign banks are much lesser than those of the domestic bank as the targeted served customers between domestic banks and foreign banks are different.

As the core banking activity, bank lending is greatly affected by the changing interest-rate environment as the profit or income from bank lending comes from the interest charged to loan borrowers. In fact, banking activities can be categorized into traditional banking activities and nontraditional banking activities. The banks derive interest income from the traditional banking activities such as personal and corporate lending. Meanwhile, the portion of non-interest income comes from the non-traditional banking activities such as insurance services, funds management, advisory services, financial market products, transaction services, and in-house trading activities.

Indeed, the banking sector plays an important role in which business finance has the most controlling power in the area. The developing financial system in Asia Pacific further emphasizes the role of banks [1]. Due to the Asian crisis in 1997, the banking industry was likely to shift its focus to non-traditional source of income to mitigate a revenue decline resulting from interest-rate risk. During that time, banks faced increasing repayment defaults among borrowers and insolvency risks while in redeeming their loans, hence, the banking sector started to emphasize more towards the non-interest-based income activities [2]. The implications may be detrimental in Malaysia as the country relies heavily on the banking sector for liquidity creation and the financing of economic activity.

Figure 1.1, 1.2, and 1.3 illustrate the non-interest income share of banking sector, insurance sector, and other financial institutions in Malaysia respectively from the year 2000 to 2019. The non-interest income share (NII share) is derived from the ratio of net non-interest income to total operating income [3]. Based on Figure 1.1, the non-interest income share in banking sector is showing an uptrend over the 20 years - from the year 2000 to 2019. This has proven that banking sector is gradually emphasizing on the noninterest-based activities. As such, this study expects a greater revenue diversification effort in banking sector. However, the trend of insurance sector is not able to be identified through NII share as refer to Figure 1.2. This may due to the reason that most of the revenue portion in insurance sector comes from premium collected, which is non-interest income. Thus, the trend line of NII share has been maintained at a level for over 20 years. Meanwhile, Figure 1.3 shows a declining trend in other financial institutions on the NII share, which might indicate lesser diversification efforts in revenue in recent years. By comparing the three sectors in financial services industry, banking sector has the strongest awareness to diversify its revenue sources. This is particularly meaningful to conduct a study on the revenue diversification in financial services industry as there is a growing potential of the non-interest income activities as shown in Figure 1.1, 1.2, and 1.3.

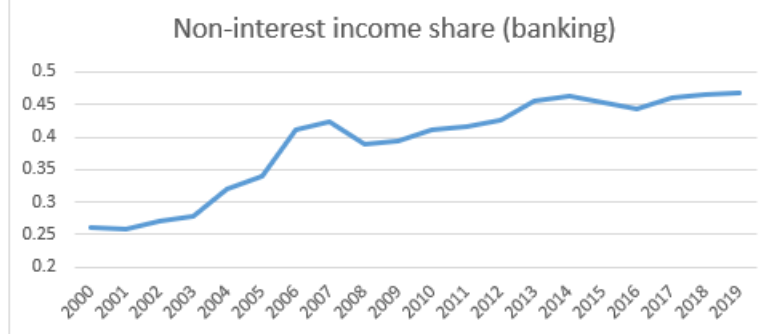

Figure 1.1: Non-interest income share of banking sector in Malaysia from year 2000 to 2019 . Source: Author's own calculation using the data from Bursa Malaysia's annual reports

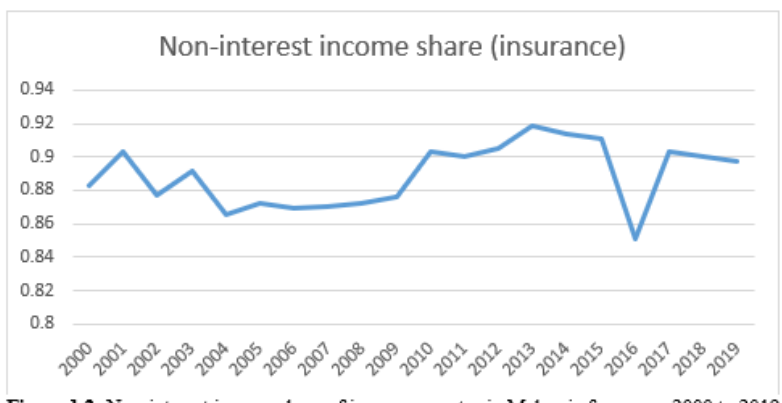

Figure 12. Non-interest income share of insurance sector in Malaysia from year 2000 to 2019 Source: Author's own calculation using the data from Bursa Malaysia's annual reports

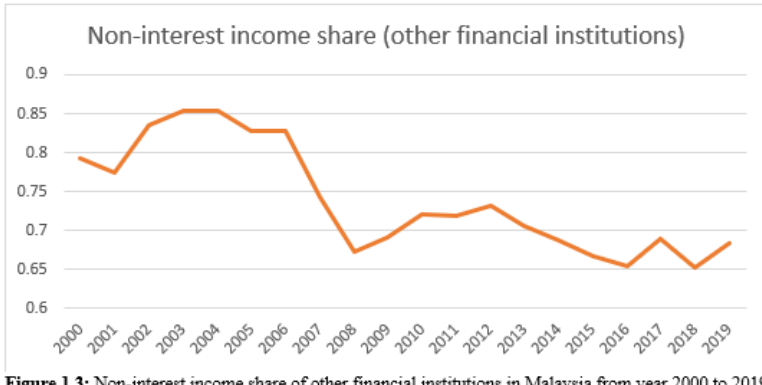

Malaysia from year 2000 to 2019 Source: Author's own calculation using the data from Bursa Malaysia's annual reports

Meanwhile, the problem is that conventional banks and other financial institutions still rely heavily on the core traditional businesses-raising deposits and lending activities and have less effort in diversifying into other alternative forms of non-interest-based activities. According to DeYoung and Torna [4], fees-based income activities would be an important alternative source of revenue by reducing the over-reliance on lending as the main source of revenue.

Meyappan, et al. [5] argued that the portion of non-interest income in banking sector in Malaysia is less than $20 \%$ of the total sector revenue in the year 2015. They contended that the banking sector in Malaysia is relying more on the traditional income activities / interest-based income activities. The truth is that interest-based products are getting less favorable due to the competition, global economic environment, lower net interest margin, and the introduction of Basel III. Thus, our study seeks to identify the significant variables in determining the diversification strategies of financial services industry in Malaysia. As 
such, financial services companies can identify and focus on these variables to increase their non-interest income.

This paper applies the analysis to Malaysia - a developing Asian economy with a well-regulated, bank-oriented financial system. This research specifically focuses on the factors that will affects the revenue diversification efforts of the financial services industry. Particularly, this paper attempts to examine the impact of sector-specific factors, macroeconomic factors, and monetary policy factors on the financial firms' business dynamic / revenue diversification. Through this analysis, the factors that are affecting the revenue diversification of each sector in financial services industry can be scrutinized.

The paper is organized as follows: Section 2 provides the literature review, Section 3 describes the data and methodology, Section 4 presents the empirical results, and Section 5 provides the conclusion.

\section{LITERATURE REVIEW}

\subsection{Environmental and economic conditions on banking margin: An overview}

The unintended consequences of environmental and economic reform are always applied to the financial services industry. In particular, the financial system of the country needs to ensure its alignment between economic growth and regulatory environment change. As regulation remains complex in Asia, different Asia Pacific financial firms may have variations on the stages of economic development. Meanwhile, some researchers identified that the environmental conditions differentiate the impact of non-interest income on bank growth, profitability and risk [6]. As a matter of fact, the years after global financial crisis, it had contributed to a more complex regulatory environment for the whole financial services industry, especially the banking sector, due to the reason that Basel committee is constantly improving to reshape and reform the global banking industry. Hence, the environmental and economic factors will be push factor for the financial sector to investigate non-interest-based activities.

The environmental factor such as financial sector transparency has also proven to be related to the bank interest margins. The findings of Kusi et al [7] revealed that financial sector transparency reduces interest margins. The study showed that economies with lower and moderately high bank interest margin level can benefit more from policies targeted at improving transparency in the financial sector. Drake et al. [8] suggested that bank-specific, industry-specific, and macroeconomic are determinants in affecting banks' profitability. The study also indicated high levels of technical inefficiency for many institutions which are influenced by trends across size groups and banking sectors, as well as the different impacts of environmental factors on different size groups and financial sectors. However, these may have come via the adverse developments in the macro-economy and its impact on bank activities.

\subsection{Firm size, systemic risk, and diversification}

Some authors had also analyzed the joint effect of nontraditional banking activities exposures to systemic risk that differ according to bank size. Related to this matter, Hughes et al. [9] reported that larger-sized banks benefit more from diversification efforts together with sophisticated risk management techniques than do smaller-sized banks. Meanwhile, Kamani [10] reported that the increasing of non-traditional banking activities, particularly non-interest income, will only increase the systemic risk exposures among smaller-sized banks and reduce the risk exposures among larger-sized banks.

\subsection{Diversification and leverage}

The studies of Chakrabarti et al. [11] and Kochhar [12] reported a positive and significant relationship between corporate leverage and product lines' diversification. Meanwhile, Monteforte and Staglianò [13] investigated the effects of diversification in product and geography on corporate leverage, which also showed a positive relationship between diversification and leverage. As such, they have raised interest among recent researchers to investigate this matter among financial institutions, as the financial sector is significantly different in few areas with the non-financial firms. First, as proposed by Memmel and Raupach [14], financial institutions can control the level of leverage more efficiently as their asset's liquidity is typically higher than that of non-financial firms. Besides, the level of leverage in financial institutions must not exceed a limit as the sector is regulated by authorities [15]. Meanwhile, the target adjustment hypothesis in previous banking literature confirmed that specialized or diversified companies tend to move towards target debt ratio [16]. Jouida and Hellara [17] investigated the relationship between diversification and leverage among French financial institutions. They figured out that both activity and geographic diversification has impacted the leverage negatively in general, which indicates that more diversified financial institutions have lower leverage ratios.

\subsection{Bank risk and diversification}

The linkage between bank risk and loans has been documented in the Gramm-Leach-Bliley Act of 1999 [18]. The Act encouraged the banks in United States to diversify their business by creating incentives for them. Not only for banks, the Act also allowed other financial firms to freely merge and compete for loans as well. As a result, the firms had larger risk exposure although they were profiting by entering new business lines. In sum, this has created intensified competition among banks in the US, which further led them to diversify into non-traditional based activities. The loans portion in financial firms' assets is always associated with risk exposure as it is exposed to higher credit risk and market risk, due to being interestlinked. When financial firms have high loan-to-asset ratios, they might face higher risk exposure. 


\subsection{Bank capital requirement and business diversification}

The discussion was then followed by the impact of bank capitalization on bank diversification. Nguyen et al. [19] reported a positive and significant relationship between bank capital and income diversification among banks in ASEAN countries, in which the authors introduced bank capital as a control variable. In a similar view, Toh [20] also showed that an increase in bank capital has positive effect on both asset and revenue diversification.

\subsection{Bank competitiveness and diversification}

Angelini and Cetorelli [21] reported that the competitive pressure from European countries have changed substantially in banking environment, with potentially offsetting effects on the overall degree of competitiveness. Competitive conditions is signaled by the decline in interest profit margin. As such, non-interest-based activities is important in the competitive landscape of the industry. Carbó Valverde [22] stated that the competition between markets and intermediaries is affected by financial integration in Europe and generates a convergence of both interest rates and margins among different countries. The research of Smith, et al. [23] stated that banks and nonbanks are diversifying into fee-earning activities due to stiff competition environment. The study of Peria and Mody [24] revealed that bank concentration is positively and directly related to both higher spreads and costs. This is related to the increasing foreign bank participation which results in higher concentration levels. The overall level of foreign bank participation seems to influence the spreads indirectly, primarily through its effect on administrative costs.

\subsection{Monetary policy and income activities diversification}

Kosmidou and Zopounidis [25] proposed that money supply does influence bank activities. When money supply grows, the inflation rate tends to increase as well, which in turn exerts the influential power on credit-taking decisions of the market. The higher nominal credit rates due to the inflation might undermine the market demand of credits. Thus, the lower market demand of credits affects the interest-based activities and revenues of financial firms as well. Indeed, this condition is backed by the money-quantity theory of Friedman and the Meltzer's monetary model whereas the author [26] identified a one-way causality from the money supply on inflation in which it can be detected from the asset inflation and financial institutions' asset pricing stability. Having discussed on the first indicator of monetary policy, the discussion turns to the second indicator, which is the interest rate. Albertazzi and Gambacorta [27] mentioned that when interest rate level is low, banks can earn more from professional services such as portfolio management as the demand among savers tends to increase. On the other hand, Bolt et al. [28] found a negative relationship between short-term interest rate and net interest income, and a positive relationship between long-term interest rate and net interest income.

Hence, this present study aimed to rectify these literature gaps by exploring a wider spectrum of determinants which can be broadly categorized into sector-specific, macroeconomic, and monetary policy, and to identify which specific types of determinants are important to the financial services industries' business diversification. This study was conducted among all listed financial-services firms in Malaysia. We hypothesized that:

$H_{1}$ : Sector-specific, macroeconomic, and monetary policy factors have impacts on income activities in Malaysian financial services industry.

By factoring in cataclysmic global financial crisis 2008/2009 impact, the following hypothesis is posited:

$\mathrm{H}_{2}$ : Sector-specific, macroeconomic, and monetary policy factors have impacts on income activities in Malaysian financial services industry during cataclysmic global financial crisis in 2008/2009.

\section{DATA AND METHODOLOGY}

Quantitative research method was carried out in this study and the secondary data was used to complete this study. The necessary data is hand-collected on the audited annual reports published on Bursa Malaysia website from the year 2000 to 2019 , particularly concentrating on the notes to the financial statements that provide the breakdown of noninterest activities into a variety of non-interest income activities in different notes and segments. All public-listed banks, insurance, and other financial institutions in Malaysia are included in this study. The accounting reporting standards had changed along time frames and some activities were not clearly mentioned and recorded in the annual reports especially in the early 2000s. However, this study can capture the observations with available data, which leads to an unbalanced panel dataset. Meanwhile, the measurements of monetary policy, money supply, and interest rate used the proxies which were obtainable from Department of Statistics (DOS) in Malaysia official portal. The whole public-listed financial-services industry in Malaysia consist of 10 banks, 9 insurance institutions, and 14 other financial institutions, which can be hyperlinked to Bank Negara Malaysia (BNM) and Bursa Malaysia. Therefore, we concluded that the sample design for this research is non-probability and is a justification sampling. Four models have been developed for each sector: a) First and second models make distinctive comparison on the effect of financial crisis dummy variable during 2008-09, b) Third and fourth models investigate the dataset separately from the year 2000 to 2007, and from the year 2010 to 2019 respectively, particularly, pre-crisis period, and post-crisis period.

The regressions in this study is estimated in the following form:

Model 1 for bank industry

$$
\begin{aligned}
\operatorname{Div}_{i t}= & \beta_{1} \mathrm{LTA}_{\mathrm{it}}+\beta_{2} \operatorname{lnCF}_{\mathrm{it}}+\beta_{3} \operatorname{lnTA}_{\mathrm{it}}+\beta_{4} \mathrm{DTA}_{\mathrm{it}} \\
& +\beta_{5} \mathrm{CAR}_{\mathrm{it}}+\beta_{6} \mathrm{BCI}_{\mathrm{it}}+\beta_{7} \mathrm{GNI}_{\mathrm{it}}+\beta_{8} \mathrm{CI}_{\mathrm{it}} \\
& +\beta_{9} \mathrm{MS}_{\mathrm{it}}+\beta_{10} \mathrm{IR}_{\mathrm{it}}+\beta_{11} \mathrm{Crisis}_{\mathrm{it}}+\varepsilon
\end{aligned}
$$




$$
\begin{aligned}
& \text { Model } 2 \text { for insurance industry and other financial } \\
& \text { institutions } \\
& \begin{aligned}
\operatorname{Div}_{i t}= & \beta_{1} \mathrm{LTA}_{\mathrm{it}}+\beta_{2} \mathrm{InCF}_{\mathrm{it}}+\beta_{3} \mathrm{InTA}_{\mathrm{it}}+\beta_{4} \mathrm{DTA}_{\mathrm{it}} \\
& +\beta_{5} \mathrm{GNI}_{\mathrm{it}}+\beta_{6} \mathrm{CI}_{\mathrm{it}}+\beta_{7} \mathrm{MS}_{\mathrm{it}}+\beta_{8} \mathrm{IR}_{\mathrm{it}} \\
& +\beta_{9} \mathrm{Crisis}_{\mathrm{it}}+\varepsilon \\
\mathrm{Div}= & \mathrm{HHI}_{\mathrm{REV}}=\left(\frac{\mathrm{IBA}}{\mathrm{TI}}\right)^{2}+\left(\frac{\mathrm{NIBA}}{\mathrm{TI}}\right)^{2}
\end{aligned}
\end{aligned}
$$

whereas the income diversification $\left(\operatorname{Div}_{i t}\right)$ is measured as the Revenue Hirschman Herfindahl Index, $\mathrm{HHI}_{\text {REV }}$ based on [3], NIBA is non-interest income, IBA is interest income, and TI is total income. The value of HHI that reaches 1.0 means that the firm only has the income, either from noninterest or interest income. Otherwise, the value will be in the range between 0.0 and 1.0. If the firm fully diversify from net interest income and non-interest income, the value will equal to $0.5 . \mathrm{LTA}_{\mathrm{it}}$ is bank risk / illiquidity (measured as the outstanding loans to total assets ratio), $\operatorname{lnCF} i$ is cash dynamic (natural $\log$ of the firm's cash flow), $\operatorname{lnTA_{it}}$ is firm size (natural $\log$ of the firm's total assets), DTA $\mathrm{it}_{\mathrm{it}}$ is book leverage (total debts to total assets ratio), $\mathrm{CAR}_{\mathrm{it}}$ is bank capital requirements (total of Tier 1 and Tier 2 capital divided by the risk-weighted assets), $\mathrm{BCI}_{\mathrm{it}}$ is bank competitiveness (bank concentration index), $\mathrm{GNI}_{\mathrm{it}}$ is gross national income $(\%), \mathrm{CI}_{\text {it }}$ is country inflation $(\%), \mathrm{MS}_{\mathrm{it}}$ is aggregate money supply $(\%), \mathrm{IR}_{\mathrm{it}}$ is country interest rate (\%) and Crisis $\mathrm{sit}_{\mathrm{it}}$ is the crisis period between 2008 and 2009 (the value given is 1 . Otherwise, the value is 0 ).

\section{RESULTS AND DISCUSSION}

\subsection{Banking sector}

Table 4.1, 4.2, and 4.3 reports the panel data analysis results for banking sector, insurance sector, and other financial institutions, respectively. First of all, Table 4.1 reports that, among the six variables under sector-specific factors, the four variables having significant impact on the business dynamic in banking sector are natural log of cash flow, natural log of total assets, debts-to-assets ratio, and bank concentration index as shown in Model 1 and Model 2.

First, cash dynamic is found positively related to income diversification index. In other words, when banks hold more cash flow, they are more focused on one revenue source. Thus, they are less likely to venture into non-traditional source of income. Bakke and $\mathrm{Gu}$ [29] mentioned that for firms to be more diversified, they are required to build up capital in new income-source activities, hence, more diversified firms hold lesser cash.

Second, the negative relationship between firm size and business dynamic can be explained by the more aggressive behavior of larger-size banks to diversify their business with non-interest income activities. As such, the larger the bank size, the greater the diversification efforts of banks will be. Besides, this may also due to the reason that the fixed costs associated with fee-based activities are influencing the larger size banks to conduct more noninterest income activities [4].
Third, the result of negative relationship between leverage and business dynamic means that a more diversified firm has higher leverage. This observation assumes that instead of using equity, banks are using more debts to fund the new income activities in acquiring more knowledge and expertise related to these new activities.

Fourth, the result of negative impact of bank competitiveness on income diversification index explains that when banks are more competitive, they tend to diversify their income source further. When banks are operating in highly-concentrated markets, banks are able to diversify into more activities, because the environment allows them to be monopolistic rather than oligopoly market structure and would therefore command the market. The degree of competition in the market may be enhanced by the increasing number of firms with uniform size, but also potentially erode profits. This is because the market players will start and initial price war on their products and services and be careful on how they fare against their competitors in terms of interest margins. Consistent to the StructureConduct-Performance (SCP) theory, when the bargaining power of buyers is weak, price takers have the opportunity to make profits in concentrated industry [23].

During the pre-crisis period, leverage, bank capital requirements, and bank competitiveness exhibit negative relationship with business dynamic in banking sector. These results are similar with Model 1 and Model 2, except for the bank capital requirements variable. The negative relationship between bank capital requirements and income diversification index indicates that when banks are highly capitalized, they are more diversified in income sources. Hence, this finding assumes that holding more equity capital will reduce tax benefits for banks when comparing with holding more deposits as debt funding that provides tax-shield, which in turn translates to a lower after-tax profits for highly capitalized banks. As a result, this further motivates banks to diversify in income sources to reduce risk and create more profits.

On the other hand, under the economic factors, only country inflation shows significant impact on income diversification index in banking sector. The observation indicates that when inflation rate is increasing, banks tend to be more diversified in income source. The higher nominal credit rates due to inflation might undermine the market demand of credits, thus, the lower market demand of credits affects the interest-based activities and revenue of financial firms as well. Therefore, banks are willing to conduct noninterest-based activities to diversify income sources [25]. Turning to monetary policy factors, money supply is found to have negative relationship with income diversification index. This indicates that banks are more diversified when money supply is higher. This is due to the reason that when money supply grows, the inflation rate tends to increase as well, which in turn exerts the influential power on credittaking decisions. Meanwhile, for interest rate, it is found to have positive impact on income diversification index. The phenomenon of financial institutions moving into nontraditional income activities during the interest rate declines can be explained by when interest rate level is low, banks 
can earn more from professional services such as portfolio management as the demand among savers tends to increase, thus, banks are willing to diversify into more non-traditional income sources [27].

\subsection{Insurance sector}

The result exhibits a negative relationship between Gross National Income and income diversification index which indicates that when Gross National Income increases, insurance companies in Malaysia tend to be more diversified between interest income and non-interest income. When the income level of citizens is higher, they tend to improve their well-being through investment activities, thus it might affect the income activities and the profitability of firms. Leverage is found to have negative impact on income diversification index in pre-crisis period (2000-2007). Meanwhile, the country inflation is negatively related to income diversification index in post-crisis period (2010-2019). These results indicate that insurance companies with higher leverage tend to be more diversified in income activities in pre-crisis period. Besides, when the inflation is higher, insurance companies are more willing to diversify their income activities.

\subsection{Other financial institutions}

Under sector-specific factors, the significant negative impact of leverage indicates that the financial institutions in Malaysia are more diversified in income activities when they have higher leverage.

Under economic factors, the result shows that other financial institutions are more diversified in income activities when Gross National Income decreases. However, this relationship is contradictive with the general view and justification that had been suggested in the insurance sector. Additionally, other financial institutions are more diversified when the inflation rate is higher [25]. The authors justified that the higher nominal credit rates due to inflation might undermine the market demand of credits, thus, the lower market demand of credits affects the interestbased activities and revenue of financial firms as well. Thus, banks are willing to conduct non-interest-based activities to diversify income sources.

Furthermore, turning to the monetary policy factors, other financial institutions tend to be more diversified in interest activities and non-interest activities when money supply declines. The relationship can be explained by the reserve requirement and prudential regulations on financial institutions, regardless the money supply grows or decreases. Xing et al. [30] stated that the countries' reserve requirement and prudential regulations limit the banks' balance sheet expansion and credit creation process. The changing monetary policy influences the reserve requirement, while financial institutions need to constantly monitor their activities as well due to the country's prudential regulation, therefore pushing them to conduct more diversifiable activities. Meanwhile, the result also shows that interest rate is positively related to income diversification index. However, it has negative relationship with income diversification index in post-crisis period. In general, financial institutions are moving into nontraditional income activities during interest rate declines. When the interest rate level is low, banks can earn more from professional services such as portfolio management as the demand among savers tends to increase, thus, banks are willing to diversify into more non-traditional income sources [27]. However, during the post-crisis period, financial institutions are moving into non-traditional income activities when the interest rate increases.

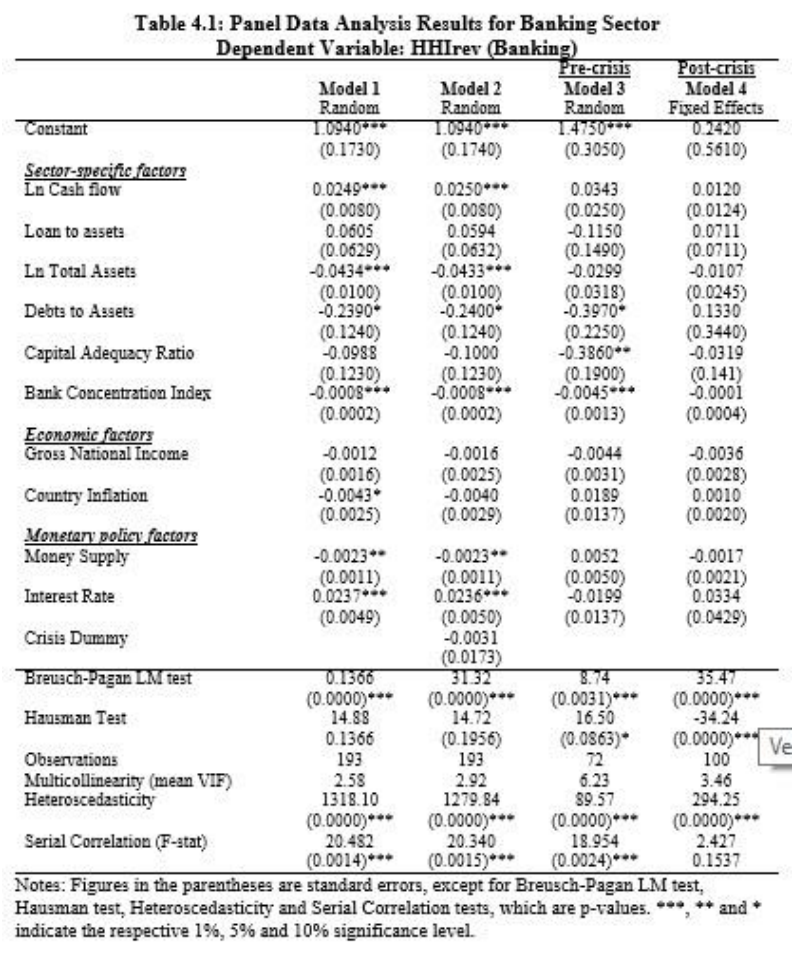

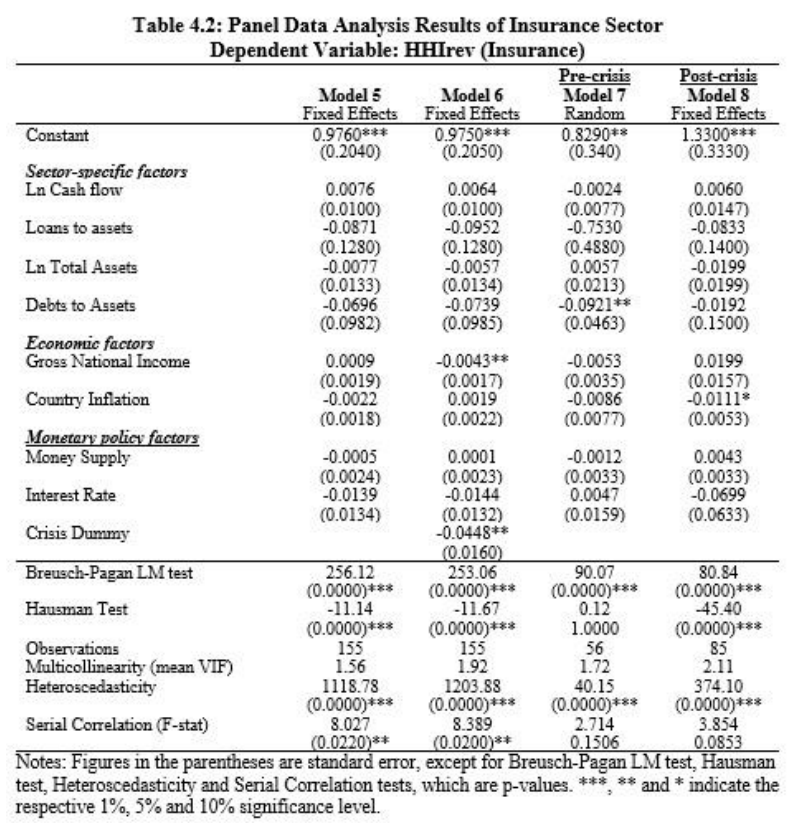




\begin{tabular}{|c|c|c|c|c|}
\hline & $\begin{array}{l}\text { Model } 9 \\
\text { Random }\end{array}$ & $\begin{array}{l}\text { Model 10 } \\
\text { Random }\end{array}$ & $\begin{array}{l}\text { Pre-crisis } \\
\text { Model 11 } \\
\text { Random } \\
\end{array}$ & $\begin{array}{l}\text { Post-crisiz } \\
\text { Model 12 } \\
\text { Random } \\
\end{array}$ \\
\hline Constant & $\begin{array}{l}0.9970 * * * \\
(0.2030)\end{array}$ & $\begin{array}{l}0.9980 * * * \\
(0.2040)\end{array}$ & $\begin{array}{l}1.7180^{* * *} \\
(0.3720)\end{array}$ & $\begin{array}{l}1.0670^{* * *} \\
(0.3710)\end{array}$ \\
\hline $\begin{array}{l}\text { Sector-specific factors } \\
\text { Ln Cash flow }\end{array}$ & -0.0056 & -0.0057 & -0.0316 & -0.0022 \\
\hline Loans to asgets & $\begin{array}{l}(0.0130) \\
0.0328\end{array}$ & $\begin{array}{l}(0.0131) \\
0.0330\end{array}$ & $\begin{array}{l}(0.0193) \\
-0.0476\end{array}$ & $\begin{array}{l}(0.0131) \\
0.0135\end{array}$ \\
\hline Ln Total Assets & $\begin{array}{l}(0.0529) \\
-0.0141 \\
(0.0108)\end{array}$ & $\begin{array}{l}(0.0530) \\
-0.0140 \\
(0.0108)\end{array}$ & $\begin{array}{l}(0.0892) \\
-0.0044 \\
(0.0123)\end{array}$ & $\begin{array}{c}(0.0592) \\
0.0177 \\
(0.0124)\end{array}$ \\
\hline Debts to Assets & $\begin{array}{c}-0.1830 * * * \\
(0.0593)\end{array}$ & $\begin{array}{c}-0.1830 * * * \\
(0.0594)\end{array}$ & $\begin{array}{l}-0.0484 \\
(0.0785)\end{array}$ & $\begin{array}{l}-0.1700 \% * \\
(0.0697)\end{array}$ \\
\hline $\begin{array}{l}\text { Economic factors } \\
\text { Gross National Income }\end{array}$ & $0.0105^{* 8}$ & 0.0110 & & $0.0311^{* *}$ \\
\hline Country Inflation & $(0.0045)$ & $(0.0073)$ & $(0.0087)$ & $(0.0133)$ \\
\hline Country Inflation & $(0.0071)$ & $(0.0083)$ & $(0.0176)$ & $\begin{array}{l}-0.02078 \\
(0.0122)\end{array}$ \\
\hline$\frac{\text { Monetarv policv factors }}{\text { Money Supply }}$ & 0.0039 & 0.0039 & -0.0017 & $0.0091^{* * *}$ \\
\hline & $(0.0027)$ & $(0.0028)$ & $(0.0074)$ & $(0.0031)$ \\
\hline Interest Kate & $\begin{array}{l}0.0251^{* 8} \\
(0.0102)\end{array}$ & $\begin{array}{l}0.0250 * 8 \\
(0.0103)\end{array}$ & $\begin{array}{l}-0.0448 \\
(0.0472)\end{array}$ & $\begin{array}{l}-0.1320^{8} \\
(0.0679)\end{array}$ \\
\hline Crisis Dummy & & $\begin{array}{l}0.0042 \\
(0.0450)\end{array}$ & & \\
\hline Breusch-Pagan LM test & 202.74 & 202.71 & 9.07 & 298.75 \\
\hline Hausman Test & 4.76 & 4.75 & 10.14 & 2.75 \\
\hline Observations & $\begin{array}{l}0.7830 \\
247\end{array}$ & $\frac{0.8554}{247}$ & $\frac{0.2552}{84}$ & 0.9491 \\
\hline Multicollinearity (mean VIF) & 1.86 & 2.23 & $\begin{array}{c}84 \\
1.79\end{array}$ & $\begin{array}{l}137 \\
2.80\end{array}$ \\
\hline Heteroscedasticity & 1492.26 & 1467.83 & 1975.30 & 2001.46 \\
\hline Serial Correlation (F-stat) & 1492.26 & 5.550 & 8.775 & 0.636 \\
\hline
\end{tabular}

\section{CONCLUSIONS}

This paper examines how sector-specific, macroeconomic, and monetary policy factors influence business dynamics using an unbalanced panel data of 33 listed financial services firms in Malaysia during the period of 2000-2019. For this reason, this study applied panel data analysis. Our estimations have established a significant relationship among business diversification, sector-specific factors, and monetary policy, along with other macroeconomic factors. Particularly, the result of sector-specific factors shows significant impacts on business dynamics across three sectors in financial services industry in Malaysia. To conclude from the empirical findings, cash dynamic, firm size, leverage, bank competitiveness, and bank capital requirements have significant effects in banking sector. Meanwhile, leverage is found to have a negative impact on income diversification index in pre-crisis period in the insurance sector. Subsequently, the negative impact of leverage on income diversification index is exhibited in 3 out of 4 models in other financial institutions. These empirical findings explain that, first, a diversified bank has lower cash holdings; Second, large-sized banks tend to be more diversified in income source; Third, a more diversified financial services firm has higher leverage (as proven by the results of three sectors); Fourth, when banks are more competitive, they tend to diversify their income source further; and Fifth, when banks are highly capitalized, they are less diversified in income sources.

On the other hand, the relationship between macroeconomic factors and business dynamics is observed in banking sector, insurance sector, and other financial institutions as well. These observations indicate that when inflation rate is increasing, banks tend to be more diversified in income source. Next, when Gross National Income increases, insurance companies in Malaysia tend to be more diversified between interest income and non-interest income. However, other financial institutions are more diversified in income activities when Gross National Income decreases.

Subsequently, both monetary policy factors show significant impact on business dynamics in banking sector and other financial institutions according to our empirical findings. First, banks are more diversified when money supply is higher, but other financial institutions tend to be more diversified in interest activities and non-interest activities when money supply declines. Second, banks and other financial institutions tend to move into non-traditional income activities during interest rate declines. Apart from this, only the post-crisis period model in other financial institutions exhibits negative relationship between interest rate and income diversification index, which indicates that other financial institutions tend to be less concentrated when the interest rate increases after financial crisis year.

With respect to policy implications, this study offers three perspectives to review on business dynamics in financial services industry. Investors and regulators can evaluate the revenue diversification from sector perspective, economic perspective, as well as monetary policy perspective. This provides a clearer picture on how the variables impact the business dynamics / revenue diversification of a financial firm. Additionally, the managers of financial firms are benefited in this study as their goal is to maximize profit, reduce risk exposure, and diversify into lower-risk revenue sources. Based on the analysis in different sectors in financial services industry, the managers can identify the relevant factors that influence the revenue diversification. By working on the relevant factors, it may be helpful in their diversification strategies. Lastly, monetary policy authorities can raise awareness as they are getting deeper insight on the impact of money supply and interest rate on revenue diversification. By making the right policy, monetary policy authorities could encourage financial firms to go venturing into newer lines of business.

\section{REFERENCES}

[1] Wade, R.1990. Governing the market: Economic theory and the role of government in East Asian industrialization, Princeton University Press.

[2] Barth, J. R., Caprio, J. and Levine, R., 2004. Guide to the 2003 World Bank Survey.

[3] Stiroh, K.J. and Rumble, A., 2006. The dark side of diversification: The case of US financial holding companies. Journal of banking \& finance, 30(8), pp.2131-2161.

[4] DeYoung, R. and Torna, G., 2013. Nontraditional banking activities and bank failures during the financial crisis. Journal of Financial Intermediation, 22(3), pp.397-421. 
[5] Meyappan, B., Yusof, R.M. and Mazlan, A.R., 2019. Moving toward non-Interest income for banking sustainability: A case study on determinants of noninterest income of CIMB Bank and RHB Bank. International Journal of Economics, Management and Accounting, 27(1), pp.105-122.

[6] Lee, C.C., Yang, S.J. and Chang, C.H., 2014. Noninterest income, profitability, and risk in banking industry: A cross-country analysis. The North American Journal of Economics and Finance, 27, pp.48-67.

[7] Kusi, B.A., Agbloyor, E.K., Gyeke-Dako, A. and Asongu, S.A., 2020. Financial Sector Transparency and Net Interest Margins: Should the Private or Public Sector lead Financial Sector Transparency? Research in International Business and Finance, 101260, pp. 1-43.

[8] Drake, L., Hall, M.J. and Simper, R., 2006. The impact of macroeconomic and regulatory factors on bank efficiency: A non-parametric analysis of Hong Kong's banking system. Journal of Banking \& Finance, 30(5), pp.1443-1466.

[9] Hughes, J.P., Lang, W.W., Mester, L.J., Moon, C.G. and Pagano, M.S., 2003. Do bankers sacrifice value to build empires? Managerial incentives, industry consolidation, and financial performance. Journal of Banking \& Finance, 27(3), pp.417-447.

[10] Kamani, E.F., 2019. The effect of non-traditional banking activities on systemic risk: Does bank size matter? Finance Research Letters, 30, pp.297-305.

[11] Chakrabarti, A., Singh, K. \& Mahmood, I. 2007. Diversification and performance: evidence from East Asian firms. Strategic Management Journal, 28, 101120.

[12] Kochhar, R., 1996. Explaining firm capital structure: The role of agency theory vs. transaction cost economics. Strategic Management Journal, 17, 713728.

[13] Monteforte, D. \& Stagliano, R., 2015. Firm complexity and capital structure: Evidence from Italian diversified firms. Managerial and Decision Economics, 36, 205-220.

[14] Memmel, C. and Raupach, P., 2010. How do banks adjust their capital ratios? Journal of Financial Intermediation, 19(4), pp.509-528.

[15] Schandlbauer, A., 2014. Deviations from the target capital structure of financial institutions. Available at SSRN 2441665.

[16] La Rocca, M., La Rocca, T., Gerace, D. and Smark, C., 2009. Effect of diversification on capital structure. Accounting \& Finance, 49(4), pp.799-826.
[17] Jouida, S., Bouzgarrou, H. \& Hellara, S. 2017. The effects of activity and geographic diversification on performance: Evidence from French financial institutions. Research in International Business and Finance, 39, 920-939.

[18] Barth, J.R., Brumbaugh, R.D. and Wilcox, J.A., 2000. Policy watch: The repeal of Glass-Steagall and the advent of broad banking. Journal of Economic Perspectives, 14(2), pp.191-204.

[19] Nguyen, M., Skully, M. and Perera, S., 2012. Market power, revenue diversification and bank stability: Evidence from selected South Asian countries. Journal of International Financial Markets, Institutions and Money, 22(4), pp.897-912.

[20] Toh, M.Y., 2019. Effects of bank capital on liquidity creation and business diversification: Evidence from Malaysia. Journal of Asian Economics, 61, pp.119.

[21] Angelini, P. and Cetorelli, N., 2006. The Effects of Regulatory Reform on Competition in the Banking Industry. Journal of Money, Credit, and Banking, 35(5), pp. 663-684.

[22] Carbó Valverde, S., López del Paso, R. and Rodríguez Fernández, F., 2007. Financial innovations in banking: Impact on regional growth. Regional Studies, 41(3), pp.311-326.

[23] Smith, R., Saikouras, C. and Wood, G., 2003. Noninterest income and total income stability, Working paper no. 198, Bank of England.

[24] Peria, M.S.M and Mody, A., 2004. How foreign participation and market concentration impact bank spreads: Evidence from Latin America. World Bank Policy Research Working Paper 3210.

[25] Kosmidou, K. and Zopounidis, C., 2008. Measurement of bank performance in Greece. SouthEastern Europe Journal of Economics, 1(1), pp.79-95.

[26] Kesavarajah, M., 2016. Tax Composition and Output Growth: Evidence from Sri Lanka. Staff Studies, 44(1-2).

[27] Albertazzi, U. and Gambacorta, L., 2009. Bank profitability and the business cycle. Journal of Financial Stability, 5(4), pp.393-409.

[28] Bolt, W., De Haan, L., Hoeberichts, M., Van Oordt, M.R. and Swank, J., 2012. Bank profitability during recessions. Journal of Banking \& Finance, 36(9), pp.2552-2564. 
[29] Bakke, T.-E. and Gu, T. 2017. Diversification and cash dynamics. Journal of Financial Economics, 123, 580-601.

[30] Xing, C., Williams, K., Hom, J., Kandlur, M., Owoyemi, P., Paul, J., Alexander, R., Shackney, E. and Barth, H., 2020. Partition dependence in financial aid distribution to income categories. Plos one, 15(4), p.e0231135. 